\title{
Determinants of Commercial Bank Profitability in Bangladesh
}

\author{
Md.Tarekur Rahman*, Shafiqul Islam Shaon** \\ * Bachelor of Business Administration, Department of Accounting\& information systems, Jagannath University,Dhaka 1100, Bangladesh \\ ** Bachelor of Business Administration, Department of Accounting\& information systems, Jagannath University,Dhaka 1100, Bangladesh
}

DOI: 10.29322/IJSRP.11.05.2021.p11356

http://dx.doi.org/10.29322/IJSRP.11.05.2021.p11356

\begin{abstract}
Commercial banks are deemed as an exigent part of the world's economy. The research paper has been ended up wholly relied on the annual reports of five years data from 2015 to 2019 , and some definite data is collected from the annual reports such as return on investment, capital adequacy ratio, cost-income ratio, debt-equity, nonperforming loan. Only the internal factors affecting the commercial bank profitability in Bangladesh is taken up into the account in this study. Some preliminary diagnoses have been used to assess the significance of data, like normality test, autocorrelation test, and heteroskedasticity test. In contrast, some statistical methods, like descriptive analysis, univariate analysis, and multiple regression, have been implemented to concluding the research. The findings show that the cost-income ratio, and debtequity ratio have been found as a negative relationship with the profitability, whereas the capital adequacy and nonperforming loan have not found any significant relationship with the profitability.
\end{abstract}

Index Terms- Profitability Analysis, Commercial Banks, Annual reports, Internal factors, Ratio Analysis

JEL Classifications: C12, C23,G21, M20

\section{INTRODUCTION}

$\mathrm{B}$ anks are the backbone of any countries, and they are especially important in emerging economies (Dawood, 2014). As a developing nation, commercial banks have greatly aided Bangladesh's economic growth. Since they are at the helm of the financial system, the factors that influence bank profitability must be studied with particular care (Dey, 2014). Internal and external variables are often used to characterize bank profitability (Athanasoglou, Brissimis \& Delis, 2005). In most countries, they are the primary financial intermediaries, offering a wide range of services (Alper and Anbar, 2011). They are more likely to provide alternative investment funds to both the public and private sectors. However, the banking sector often faces a number of problems because of weak regulations and supervision, a lack of good leadership, and non-compliance with professional principles, all of which can lead to different forms of financial scams, for example money laundering and non-performing loans.

In recent time, non-performing loan (NPL) has been opined that high non-performing loan stocks can restrict the banks' ability to lend, reducing the effectiveness of monetary policy. The ratio of non-performing loans to total loans determines the bank's asset quality. On the flip hands, it reflected the health of the bank's loan portfolio. The loan portfolio's efficiency decreases as the NPL ratio rises, resulting in lower profitability (Sarker \& Sultana, 2017).

Capital adequacy: The capital adequacy ratio, also known as the capital-to-risk weighted assets ratio, is being used to protect depositors and promote banking system stability and performance around the world. Deposited savings are the primary source of liquidity for banks and play a major role in their profitability. Greater deposits indicate a high profit, while limited deposits indicate a limited profit (Dawood, 2014).

The cost-to-income ratio: is the best financial measure, especially in valuing banks. It reflects a company's expenses in relation to its revenue. The ratio works for investors intending to give a good picture of how well the company is operated - the lower the amount, the more profitable the bank will be.

ROA has been used as a dependent variable in this study. It is the most ubiquitously used as a bank profitability benchmark because it allows us to determine the firm's return on investment (ROA) in a system that is easily comparable to that of other organizations. ROA is a ratio of net income provided by total assets over a specified time span. However, it assesses the efficacy of a product (Sufian and Habibullah,2009).

Sufian and Habibullah (2009), from 1997 to 2004, he studied the performance of thirty seven Bangladeshi commercial banks on the basis of annual report. They meticulously observed the characteristics of banks, such as loan intensity, credit risk, and cost, which had favorable and visible repercussions on the effectiveness of banks. Non-interest earning, on the other hand, have a negative correlation with bank profitability. Empirical findings exhibit that size hurts on return on average equity (ROAE), whereas it is contrary in terms net interest margins and ROAA. Due to the influence of macroeconomic measures, they did not find any noteworthy influence on bank profitability, excluding inflation, which negatively relates to banks profitability.

Tunay and Silpar (2006), they looked at the profitability of Turkish banks from 1988 to 2004. The ratios of non-interest expenses to total assets, equity, national income, and concentration ratio have been found to have a positive impact on ROE. As a result, the deposit-to-stock market capitalization ratio has a unfavorable impact on ROA and ROE.

The overall aim of study is to find out more about is to scrutinize the profitability of 28 selected banks in Bangladesh and find out the specific determinants that have profound effect on the earning of banks. At the same time, we try to detect the ratios 
which one does not affect profitability. Even though Bangladesh has 33 commercial banks, we have extracted data from 28 commercial banks because few banks have newly established after 2014, like Community bank, Shimanto bank, etc.

\section{LITERATURE REVIEW}

Financial performances of banks are measured by different authors all over the world utilizing various methods such as the most widely used methods include financial ratio analysis, pattern analysis, and CAMEL ranking. Findings of several studies are given below. Prior research on bank profitability ware conducted by Short (1979) and Bourke (1989) respectively. The results of several published findings were then used to assess the factors that influence the bank performance. Banks profitability are usually measured on the basis of two factors like internal and external. Internal factors are bank Size, capital, deposits, liquidity, management quality and financial risk, while the external factors are GDP, interest rate ,exchange rate, inflation rate, unemployment rate (Sarwar1-2018). (Shakila-2019), she did the research on the determinants of bank profitability. The study's main goal is to compare the profitability analysis of four different types of banks: State Commercial Banks, Development Financial Institutions, Private Commercial Banks, and Foreign Commercial Banks, in terms of Return on Assets (ROA) and Return on Equity (ROE), with performance patterns from 2009 to 2016.

\begin{tabular}{|c|c|c|}
\hline Author & Description & \\
\hline \multirow[t]{5}{*}{ Tarawneh(2006) } & Focus Region & Analysis of the financial results of five Omani commercial banks \\
\hline & Time & 1999 to 2003 \\
\hline & Method & $\begin{array}{l}\text { To understand the effect of asset management, operating quality, and } \\
\text { bank size on the financial performance of five commercial banks in } \\
\text { Oman, a simple regression was used. }\end{array}$ \\
\hline & Findings & $\begin{array}{l}\text { The financial performance of the banks was heavily influenced by } \\
\text { operational productivity, asset management, and the size of the bank. . }\end{array}$ \\
\hline & Relationship & $\begin{array}{l}\text { The liquidity and solvency ratios, as well as the turnover ratio, have a } \\
\text { favorable and significant consequences on the profitability, according to } \\
\text { the research result from panel data estimations on the mentioned banks. }\end{array}$ \\
\hline \multirow[t]{5}{*}{ Almazari(2011) } & Focus Region & $\begin{array}{l}\text { An examination of the financial performance of a number of Jordanian } \\
\text { commercial banks }\end{array}$ \\
\hline & Time & 2005 to 2009 \\
\hline & Method & $\begin{array}{l}\text { The thesis relied on simple regression analysis. Bank size, asset } \\
\text { management, and operating efficiency were independent variables, while } \\
\text { return on asset and interest income were dependent variables. }\end{array}$ \\
\hline & Findings & $\begin{array}{l}\text { Bigger total deposits, credits, assets, and shareholders' equity did not } \\
\text { seem to have a significant impact on bank profitability, according to the } \\
\text { report. }\end{array}$ \\
\hline & Relationship & $\begin{array}{l}\text { There is a positive association between financial performance, asset size, } \\
\text { asset use, and operational efficiency. }\end{array}$ \\
\hline \multirow[t]{5}{*}{$\begin{array}{l}\text { Ashraf and } \\
\text { Rehman (2011) }\end{array}$} & Focus Region & $\begin{array}{l}\text { Pakistani Islamic and traditional banks ware compared and their } \\
\text { performance was analyzed. }\end{array}$ \\
\hline & Time & 2007 to 2010 \\
\hline & Method & $\begin{array}{l}\text { To assess the financial performance of banks, five different dimensions } \\
\text { were chosen: I profitability, ii) earnings, iii) liquidity, iv) credit risk, and } \\
\text { v) asset operation. }\end{array}$ \\
\hline & Findings & $\begin{array}{l}\text { The study concluded that increased operating cost and inefficiency of } \\
\text { management kept Islamic banks of Pakistan far away from the } \\
\text { performance of the conventional banks. }\end{array}$ \\
\hline & Relationship & $\begin{array}{l}\text { Profitability and loan trading have been found to have a good } \\
\text { relationship, although cost management has been found to be less } \\
\text { effective in both banking sectors. }\end{array}$ \\
\hline
\end{tabular}




\begin{tabular}{|c|c|c|}
\hline \multirow[t]{4}{*}{ Ani,W.U(2012) } & Focus Region & $\begin{array}{l}\text { The aim of the study was to learn more about the factors that influence } \\
\text { commercial bank profitability in Nigeria. }\end{array}$ \\
\hline & Time & 2001 to 2010 \\
\hline & Methods & $\begin{array}{l}\text { In order to estimate the coefficient, the researchers used ordinary least } \\
\text { squares. }\end{array}$ \\
\hline & Finding & $\begin{array}{l}\text { According to a report, the size of a bank has no correlation on its profit } \\
\text { in Nigerian commercial banks. However, a higher capital asset ratio } \\
\text { boosts a bank's profitability. }\end{array}$ \\
\hline & Relationship & $\begin{array}{l}\text { The relationship demonstrates that a bank's size may have a negative } \\
\text { impact on its profitability. Asset composition (the proportion of gross } \\
\text { loans and advances to total assets) has a favorable connection with } \\
\text { profitability. }\end{array}$ \\
\hline \multirow[t]{4}{*}{ Hoffmann (2011) } & Focus Region & $\begin{array}{l}\text { In the United States of America, the study looked into the factors that } \\
\text { affect bank profitability. }\end{array}$ \\
\hline & Time & 1995 to 2007 \\
\hline & Methods & $\begin{array}{l}\text { Internal and external factors influencing bank profitability in the } \\
\text { economy were taken into account in the research. }\end{array}$ \\
\hline & Findings & $\begin{array}{l}\text { According to the study, the capital ratio and profitability have a } \\
\text { unfavorable relationship that agrees with the notion that banks are careful } \\
\text { about their working process and it also dismisses potential profitable } \\
\text { trading chances. Furthermore, cost advantages on bank size have no } \\
\text { effect on the banking industry's viability in the United States. }\end{array}$ \\
\hline
\end{tabular}




\begin{tabular}{|c|c|c|}
\hline & Relationship & $\begin{array}{l}\text { According to the empirical results, there is a negative relationship } \\
\text { between the capital ratio and profitability. }\end{array}$ \\
\hline \multirow[t]{5}{*}{ Lipunga (2014) } & Focus Region & $\begin{array}{l}\text { The study investigated the profitability of listed commercial banks in } \\
\text { developing countries focusing on Malawi }\end{array}$ \\
\hline & Time & 2009 to 2012 \\
\hline & Method & $\begin{array}{l}\text { Correlation and multivariate regression analysis was developed to } \\
\text { conduct the study. }\end{array}$ \\
\hline & Findings & $\begin{array}{l}\text { The outcome of the study suggests that ROA is influenced by liquidity, } \\
\text { bank size, and management performance, while capital adequacy has a } \\
\text { minor effect. }\end{array}$ \\
\hline & Relationship & $\begin{array}{l}\text { Bank scale, capital adequacy, and management efficiency have a } \\
\text { favorable effect on ROA, while liquidity has a negative impact on } \\
\text { profitability. }\end{array}$ \\
\hline \multirow[t]{5}{*}{$\begin{array}{l}\text { Rahaman } \\
\text { Akter, } 2015\end{array}$} & Focus Region & $\begin{array}{l}\text { Examine the effect of a few main bank-specific factors on the profitability } \\
\text { of Islamic banks in Bangladesh. }\end{array}$ \\
\hline & Time & 2009 to 2013 \\
\hline & Method & Linear multiple regression analysis technique used for the study. \\
\hline & Findings & $\begin{array}{l}\text { Results indicates that size of bank and deposit have huge unfavorable } \\
\text { effect on (ROA), although equity has been shown to have a substantial } \\
\text { positive effect. Bank profitability is unaffected by loan and expense } \\
\text { management. . }\end{array}$ \\
\hline & Relationship & $\begin{array}{l}\text { The relationship between profitability and capital adequacy is positive. } \\
\text { The efficiency of Islamic banks is harmed by operating expenses and } \\
\text { asset quality (NPL). }\end{array}$ \\
\hline
\end{tabular}

Sayilgan and Yildirim( 2009), based on data from 2002 to 2007 , examined the relationship between return on assets and return on equity ratio for a sample of Turkish banks using monthly data. The banking sector's profitability appears to have increased in tandem with lower inflation, a steadily rising industrial output index, and improved budget balance. Profitability is positively influenced by capital adequacy, while growing off-balance sheet assets has a negative impact.

Owing to differences in the setting and data used in the study, the findings of the studies differ a lot. Nonetheless, a number of researchers have established common factors that influence profitability. Various indicators of costs are usually negatively linked to earnings, according to the findings of numerous studies. Larger bank sizes, a greater dependence on loans for revenue, higher market concentration, higher GDP growth, and a higher proportion of equity capital to assets have all been related to higher profitability.

\section{METHODOLOGY}

\subsection{Data Collection \& Sample Size}

The research solely has based on penal data, which I have extracted data from the annual reports between the period of 5 years from 2015 to 2019 of 28 commercial banks operating in Bangladesh. The total observation is 140. In order to get a tentative result, To evaluate the hypothesis, descriptive figures are used in my study, (such as minimum, maximum, mean, median and standard deviation), univariate analysis, and multiple regression analysis. The research mainly scrutinizes the repercussions between profitability and the internal factors on the bank's profitability. 
3.2. Model

\begin{tabular}{|l|l|l|l|}
\hline Variables & Measure & $\begin{array}{l}\text { Type of } \\
\text { variable }\end{array}$ & Notation \\
\hline $\begin{array}{l}\text { Return on } \\
\text { Asset }\end{array}$ & $\begin{array}{l}\text { Return on Assets } \\
\text { (ROA) =Net } \\
\text { Profit/Total Assets }\end{array}$ & Dependent & ROA \\
\hline $\begin{array}{l}\text { Cost to } \\
\text { Income Ratio }\end{array}$ & $\begin{array}{l}\text { Total cost/Total } \\
\text { income }\end{array}$ & $\begin{array}{l}\text { Independe } \\
\text { nt }\end{array}$ & CIR \\
\hline $\begin{array}{l}\text { Debt to } \\
\text { Equity Ratio }\end{array}$ & $\begin{array}{l}\text { Total debt/Total } \\
\text { equity }\end{array}$ & $\begin{array}{l}\text { Independe } \\
\text { nt }\end{array}$ & DER \\
\hline $\begin{array}{l}\text { Nonperformi } \\
\text { ng loan Ratio }\end{array}$ & $\begin{array}{l}\text { Non } \\
\text { Performing/classifi } \\
\text { ed loans (NPLs) }\end{array}$ & $\begin{array}{l}\text { Independe } \\
\text { nt }\end{array}$ & NPL \\
\hline $\begin{array}{l}\text { Capital } \\
\text { Adequacy } \\
\text { Ratio }\end{array}$ & $\begin{array}{l}\text { Total equity/Total } \\
\text { assets }\end{array}$ & $\begin{array}{l}\text { Independe } \\
\text { nt }\end{array}$ & $\begin{array}{l}\text { Capital } \\
\text { Adequac } \\
\text { Ratio }\end{array}$ \\
\hline
\end{tabular}

We have used panel data to investigate the factors that influence bank profitability. A panel data, also known as longitudinal data, is a data set that includes both time series and cross-sectional components. When ROA is dependent variable,

$$
Y_{i, t}=\beta_{0}+\beta_{1} X_{i, t}+\beta_{2} X_{i, t}+\beta_{3} X_{i, t}+\beta_{4} X_{i, t}+\epsilon
$$

Independent variables are as follow:

\begin{tabular}{|c|c|}
\hline $\mathrm{X} 1=\mathrm{Cost}$ & \\
\hline $\mathrm{X} 2=\mathrm{Debt}$ & \\
\hline X3=Non & \\
\hline $\begin{array}{l}\mathrm{X} 4=\text { Capital } \\
\mathrm{t}=5 \text { years }(20\end{array}$ & $\begin{array}{l}\text { Adequacy } \\
\text { to } 20190 \varepsilon=\end{array}$ \\
\hline
\end{tabular}

\subsection{Preliminary test}

\subsubsection{Normality test}

TheJarque-Bera test is defined be the following rule:

$\mathrm{JB}=\mathrm{n}\left[\mathrm{S}^{2} / 6+(\mathrm{K}-3)^{2} / 24\right]$

$\mathrm{n}=$ total sample

$\mathrm{S}=$ skewness

$\mathrm{K}=$ kurtosis

In our model, the value of skewness and kurtosis are .030930 and 2.269488 respectively. At a 5\% level of importance, the Jarque-Bera test yields a result of 3.135270. It indicates that it is lower than the critical value that is why we are unable to dismiss the null hypothesis. On the basis of obtaining result because the value of probability is $.208538>.05$. Therefore, the model does not the violate the normality test.

\section{Jarque-Bera Test}

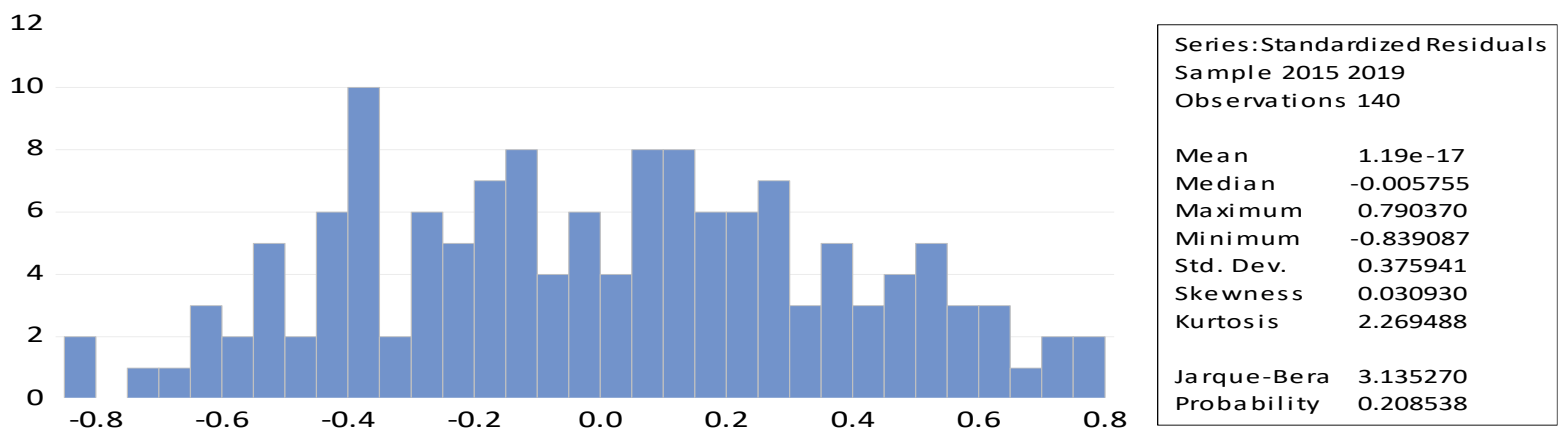

Figure: 1

\subsubsection{Autocorrelation Test}

$\mathrm{Ho}=$ There is no serial correlation.

$\mathrm{Ha}=$ There is serial correlation.

Breusch-Godfrey Serial Correlation LM Test:

Null hypothesis: No serial correlation at up to 4 lags

\begin{tabular}{llll}
\hline \hline F-statistic & 5.931120 & Prob. F(4,131) & 0.0002 \\
Obs*R-squared & 21.46672 & Prob. Chi-Square(4) & 0.0003 \\
\hline \hline
\end{tabular}

We accept alternative hypothesis because the probability of Obs R-squared is less than .05 that means there is a serial correlation up to 4 leg.

\section{3..4.3: Heteroskedasticity Test}

In a linear regression model, heteroskedasticity is used to determine if the error terms are normally distributed or not. It determines whether the variance of a regression's errors is influenced by the values of the independent variables.

$\mathrm{Ho}=$ There is no heteroskedasticity.

$\mathrm{Ha}=$ There is heteroskedasticity problem. 
Heteroskedasticity Test: Breusch-Pagan-Godfrey

Null hypothesis: Homoskedasticity

\begin{tabular}{llll}
\hline \hline F-statistic & 9.027634 & Prob. F(4,135) & 0.0000 \\
Obs*R-squared & 29.54508 & Prob. Chi-Square(4) & 0.0000 \\
Scaled explained SS & 94.83549 & Prob. Chi-Square(4) & 0.0000 \\
\hline \hline
\end{tabular}

In synopsis, we accept the alternative hypothesis since the value prob.Chi-square is less than .05 that is why we can conclude the table as a heteroskedasticity.

\section{Analysis and Findings}

\subsection{Descriptive Analysis:}

For the study period, the mean and median ROA for Bangladeshi selected commercial banks are .863 and.860, respectively, while the lowest value is -5.87 , and the highest value is 3.810. A couple of facts that the standard deviation of data set is .913 that is low indicate less variations but it's nearer to the average. There is a high chance of elevating profit margin.

For the study period, the mean and median ROA for Bangladeshi selected commercial banks are .863 and.860, respectively, while the lowest value is -5.87 , and the highest value is 3.810. A couple of facts that the standard deviation of data set is .913 that is low indicate less variations but it's nearer to the average. There is a high chance of elevating profit margin.

For the study period, the mean and median ROA for Bangladeshi selected commercial banks are .863 and.860, respectively, while the lowest value is -5.87 , and the highest value is 3.810. A couple of facts that the standard deviation of data set is .913 that is low indicate less variations but it's nearer to the average. There is a high chance of elevating profit margin.

\section{Descriptive Analysis}

\begin{tabular}{|c|c|c|c|c|c|}
\hline & $\begin{array}{l}\text { Maximu } \\
\text { m }\end{array}$ & $\begin{array}{l}\text { Minimu } \\
\text { m }\end{array}$ & $\begin{array}{l}\text { Std. } \\
\text { Deviati } \\
\text { on }\end{array}$ & $\begin{array}{l}\text { Mea } \\
\text { n }\end{array}$ & $\begin{array}{l}\text { Media } \\
\text { n }\end{array}$ \\
\hline ROA & 3.810 & -5.87 & .913 & .863 & .860 \\
\hline CIR & 182.40 & 30.77 & 17.120 & $\begin{array}{l}53.70 \\
3\end{array}$ & 50.64 \\
\hline DER & 50.1 & -9.897 & 6.368 & $\begin{array}{l}11.43 \\
7\end{array}$ & 10.885 \\
\hline NPL & 50.39 & .2 & 7.063 & 6.276 & 4.97 \\
\hline $\begin{array}{l}\text { Capital } \\
\text { adequa } \\
\text { cy }\end{array}$ & 26.29 & -14.24 & 4.148 & $\begin{array}{l}12.76 \\
8\end{array}$ & 12.800 \\
\hline
\end{tabular}

Table: 1

Non-performing loan ratios have mean and median values of 6.276 and 4.97, respectively. Over the study duration and given data set, The NPL ratio indicates that the minimum value is. 2 and the maximum value is 50.39. NPL has experienced a standard deviation equal to 7.063 , close to the mean value in the provided data set. As a result, we can conclude that there is a low disperse between the ratio of NPL.
In terms of Capital adequacy stands for the values of median and mean equal to12.800 and 12.768 respectively. The minimum and maximum values of the assigned data set are -14.24 and 26.29, respectively. The standard deviation of our data set is 4.148 , which is lower than the mean value.

\subsection{Univariate Analysis}

Correlation Analysis: The relationship between the variables is usually defined by correlation analysis.

Correlation Matrix

\begin{tabular}{|l|l|l|l|l|l|}
\hline ROA & 1 & & & & \\
\hline CIR & $-.572^{* *}$ & 1 & & & \\
\hline DER & -.142 & -.041 & 1 & & \\
\hline NPL & $-.631^{* *}$ & $.651^{* *}$ & -.047 & 1 & \\
\hline $\begin{array}{l}\text { CAPITAL } \\
\text { adequacy }\end{array}$ & $.625^{* *}$ & $-.537^{* *}$ & .066 & $-.744^{* *}$ & 1 \\
\hline
\end{tabular}

Table :2

**. Correlation is significant at the 0.01 level (2-tailed).

CIR and ROA have a deep negative relationship at $1 \%$ level of significant. In contrast, DER has a poor negative relationship with ROA and CIR. There is a blend correlation between the variables (strong negative relationship with ROA, fragile negative relationship with DER, and rigid favorable relationship with CIR) in terms of NPL. Capital adequacy has a strong positive relationship with ROA, but a strong negative relationship with CIR, NPL.

\subsection{Multiple Regression: Regression Analysis}

Since the r-squared value is $80.80 \%$, which demonstrates that there is a high chance to become feasible. F-statistic: It's used to figure out how important a model is in general. The dependent variable is strongly influenced by all of the independent variables in the model except capital adequacy and NPL ratios. Because of F-statistics is greater than the F-critical then we can conclude that all the variables are significant. In terms of Prob(F-statistic): As the Prob (F-statistic) less than 0.01 that is why we can say that all the variables associated in the model significantly affect the dependent variable at $1 \%$ significance level. Durbin-Watson stat: It tells us whether our model suffers 'serial correlation problems or not. Since the Durbin-Watson stat value is 2.01 that is almost equal to 2, which demonstrates there is negative correlation. 


\begin{tabular}{|c|c|c|c|c|}
\hline $\begin{array}{l}\text { Dependent Variable: R } \\
\text { Method: Panel Least Sa } \\
\text { Date: } 04 / 19 / 21 \text { Time: } 2 \\
\text { Sample: } 20152019 \\
\text { Periods included: } 5 \\
\text { Cross-sections include } \\
\text { Total panel (balanced) } \\
\text { Cross-section SUR (PC }\end{array}$ & $\begin{array}{l}\text { ares } \\
28 \\
28 \\
\text { servations: } \\
\text { E) standard }\end{array}$ & $\begin{array}{l}40 \\
\text { errors \& covar }\end{array}$ & nce (d.f. corr & rected) \\
\hline Variable & Coefficient & Std. Error & $\mathrm{t}$-Statistic & Prob. \\
\hline C & 3.42515 & 0.90065 & 380297 & \\
\hline CAPITAL_ADEQUICY & 0.056856 & 0.034973 & 1.625684 & 0.1069 \\
\hline$\overline{\mathrm{C} I \mathrm{R}}$ & -0.039082 & 0.012706 & -3.075844 & 0.0027 \\
\hline DER & -0.094466 & 0.022402 & -4.216828 & 0.0001 \\
\hline NPL & -0.015723 & 0.016001 & -0.982634 & 0.3280 \\
\hline & Effects $S$ & fication & & \\
\hline Cross-section fixed (du & my variables & & & \\
\hline Root MSE & 0.401365 & R-squared & & 0.808086 \\
\hline Mean dependent var & 0.878453 & Adjusted R-s & juared & 0.753000 \\
\hline S.D. dependent var & 0.919482 & S.E. of regre & sion & 0.456974 \\
\hline Akaike info criterion & 1.469251 & Sum square & resid & 22.55312 \\
\hline Schwarz criterion & 2.141626 & Log likelihoo & & -70.84757 \\
\hline Hannan-Quinn criter. & 1.742484 & F-statistic & & 14.66946 \\
\hline Durbin-Wats on stat & 2.015327 & Prob(F-statis & & 0.000000 \\
\hline
\end{tabular}

Figure:4

Level of significance $1 \%, 5 \%$

Capital adequacy is insignificant positive relationship to ROA. Insignificant relationship means that if capital adequacy is either increases or decreases, but profitability will not be affected by changes of capital adequacy. Cost-income ratio and debtequity ratio hurt on profit and significant at $1 \%$. A negative relationship depicts when profitability increases cost efficiency and DER decrease. There is a no relationship found in terms of NPL with profitability.

\section{Findings are regarding on the aforementioned regression analysis:}

$>$ The low profitability is caused by a high-cost income ratio, which shows that costs are increasing faster than profits, and this ratio gives us a good picture of how effectively the company is run. The negative value of the coefficient shows that cost efficiency and profitability have a negative relationship. It denotes a decline in cost efficiency as profitability rises. According to ( Dawood,2014) study, the research has been showed a similar relationship exists, implying a negative coefficient.

$>$ Despite the fact that the most of the researcher has founded the capital adequacy ratio as a positive relationship with profitability, we fail to detect such kind of relationship. Even there is a no relationship with profitability. Capital adequacy ratio means a bank's ability to pay liabilities and respond to credit risks and operational risks. Either high profitability or high capital adequacy ratio means enough capital to protect depositors' money. However, Lipunga (2014) showed a positive relationship with profitability.

$>$ There is a negative relationship with profitability in terms of debt-equity ratio, and It indicates when profitability increases debt-equity ratio decreases. It also depicts how much risk with stock associate with shareholders.

$>$ NPL is identified as an insignificant negative relationship with profitability. This means that nonperforming assets (NPLs) do not result in any kind of benefit for commercial banks, or that banks are unable to generate profit from scale economies. Although it usually demonstrates the effectiveness of a bank in receiving repayments on its loans and investors can view the NPL ratio that is used to select whether they invest their money or not, there is a no impact on profitability regarding the regression model. According to (Rahaman \& Akter,2015) they showed a negative impact on profitability. There may be numerous reasons of being different result like, GDP, bank rate and total amount of remittance are not same in comparison to past.

\section{CONCLUSION}

Profitability is taken into account as a key indicator to evaluate the degree of performance of banks. The determinants of this study have been established, which implicitly affect the commercial banks' profitability in Bangladesh. With a view to conclude this aim, the research would shed light on the panel data method which is used to get tentative results, and data is collected from the banks' financial statements from 2015-2019. We run a regression model intending to decide how much ROA has swayed by the independent variable. The R-squared value of the regression model is approximately $80 \%$ that has depicted an excellent regression model. Apart from that, ratio analysis is regarded as a vital management method for improving shareholders' perception of financial results and patterns over time, as well as providing critical measures of organizational success. Managers, on the other hand, often use ratio analysis to identify strengths and weaknesses from which to develop strategies and initiatives. In terms of profitability study, not all research findings are the same. There are some justifications to be shared because of occurring blend results like the financial condition of all countries is not same. Some are developed countries, and some are developing countries that is why rules and regulations, which are prepared by central bank, vary from to country.

Further research might be done on some fields by incorporating more internal variables like loans, bank size, equity, TIER -1, TIER -2, credit risk and bank charges, and external factors.

\section{REFERENCES}

[1] Almazari, A.A. (2011) Financial Performance Evaluation of Some Selected Jordanian Commercial Banks. International Research Journal of Finance and Economics, 68, 50-63.

[2] Alper, D., \& Anbar, A. (2011). Bank specific and macroeconomic determinants of commercial bank profitability: Empirical evidence from Turkey. Business and Economics Research Journal, 2, 139-152. 
[3] Ashraf, M. M., and Rehman, Z. (2011). The Performance Analysis of Islamic and Conventional Banks: The Pakistan's Perspective. Journal of Money, Investment and Banking, ISSN 1450 288X, Issue 22.

[4] Athanasoglou, P. P. (2011). Bank Capital and Risk in the South Eastern European Region. SSRN Electronic Journal. Published. https://doi.org/10.2139/ssrn.1774585

[5] Benyon, D. (1995). Book review. User Modeling and User-Adapted Interaction, 4(2), 139-141. https://doi.org/10.1007/bf01099431

[6] Bourke, P. (1989). Concentration and other determinants of bank profitability in Europe, North America and Australia. Journal of Banking \& Finance, 13(1), 65-79. https://doi.org/10.1016/0378-4266(89)90020-4

[7] Dawood,U. (2014). Factors impacting profitability of commercial banks in Pakisthan. International Journal of Scientific and Research Publications, 4(3).

[8] Dey, M. (2014). Profitability of Commercial Banks in Bangladesh:A Multivariate Analysis. IOSR Journal of Business and Management, 16(4), 92-95. https://doi.org/10.9790/487x-16439295

[9] Islam,M.A., Sarker,M.N.I., Rahman,M., Sultana.A, \& Prodhan,A.S.(2017). Determinants of Profitability of Commercial Banks in Bangladesh. International Journal of Banking and Financial Law. 1(1).

[10] Lipunga, A. M. (2014). Determinants of Profitability of Listed Commercial Banks in Developing Countries: Evidence from Malawi. Research Journal of Finance and Accounting, 596.

[11] Rahaman, M. M., \& Akhter, S. (2016). Bank-Specific Factors Influencing Profitability of Islamic Banks in Bangladesh. Journal of Business and Technology (Dhaka), 10(1), 21-36. https://doi.org/10.3329/jbt.v10i1.26904

[12] Saona, P. (2016). Intra- and extra-bank determinants of Latin American Banks' profitability. International Review of Economics \& Finance, 45, $197-$ 214. https://doi.org/10.1016/j.iref.2016.06.004

[13] Sarwar,B., Mustafa,G., Abid,A.\& Ahmad,N.(2018). Internal and External Determinants of Profitability: A Case of Commercial Banks of Pakistan. A Research Journal of Commerce, Economics, and Social Sciences, 12(1). 3843. https://doi.org/ 10.24312/paradigms 120106
[14] Sayilgan, G. and Yildirim, O. (2009). Determinants of Profitability in Turkish Banking Sector: (2002-2007), International Research Journal of Finance and Economics, 28, pp. 207-213.

[15] Short, B. K. (1979). The relation between commercial bank profit rates and banking concentration in Canada, Western Europe, and Japan. Journal of Banking \& Finance, 3(3), 209-219. https://doi.org/10.1016/03784266(79)90016-5

[16] Sufian, F., \& Habibullah, M. S. (2009). DETERMINANTS OF BANK PROFITABILITY IN A DEVELOPING ECONOMY: EMPIRICAL EVIDENCE FROM BANGLADESH. Journal of Business Economics and Management, 10(3), 207-217. https://doi.org/10.3846/16111699.2009.10.207-217

[17] Tarawneh, M. (2006). A comparison of financial performance in the Banking sector Some evidence from Omani commercial banks. International Research Journal of Finance and Economics. 3, 101-112

[18] U., W. (2012). An empirical assessment of the determinants of bank profitability in Nigeria: Bank characteristics panel evidence. Journal of Accounting and Taxation, 4(3), 38-43. https://doi.org/10.5897/jat11.034

\section{AUTHORS}

First Author - Md.Tarekur Rahman, Bachelor of Business Administration, Department of Accounting\& information systems, Jagannath University,Dhaka 1100, Bangladesh.Email: rahmant981@gmail.com. Mobile:01688838955

Second Author - Shafiqul Islam Shaon, Bachelor of Business Administration, Department of Accounting\& information systems, Jagannath University,Dhaka 1100, Bangladesh.Email: shaon.shafiq@gmail.com, Mobile:01822528692 